\title{
CD4+ T lymphocytopenia associated with sideropenia: case report
}

\author{
Linfocitopenia T CD4+ associada à sideropenia: relato de caso
}

Fernanda Bernadelli De Vito ${ }^{1}$, Juliana Lima Ribeiro ${ }^{2}$, Ane Rose Lopes Silva ${ }^{3}$, Helio Moraes de Souza ${ }^{4}$

\begin{abstract}
Importance of the issue: Idiopathic CD4 T Iymphocytopenia is an unusual immune defect in which there is an unexplained deficit of CD4 T cells. This case presents a 39-year-old female patient, with CD4+ T lymphocytopenia, who was not infected with immunosuppressive viruses neither was she subjected to immunosuppressive therapies. Comments: While monitoring the patient, she was found to have very low serum ferritin and, after parenteral iron therapy, there were changes in CD4+ cell levels, indicating that, in this case, lymphocytopenia was secondary to sideropenia. The patient is being kept under strict control of serum iron and periodic immunological evaluation, and she has not showed any clinical and/or laboratory adverse events so far. It is known that iron deficiency is an important factor in the genesis of immunological changes that occur in patients with iron deficiency anemia. It is important to understand the effects of iron deficiency on the immune system due to its high prevalence worldwide. Moreover, it could also help to clarify several cases of idiopathic CD4 lymphocytopenia.
\end{abstract}

Keywords: T-Lymphocytopenia, Idiopathic CD4-Positive. Iron Deficiency. Case Reports.

\begin{abstract}
RESUMO
Importância da questão: Linfocitopenia T CD4+ idiopática é um defeito imune incomum em que há um déficit inexplicável de células T CD4. Este caso clínico apresenta uma paciente do sexo feminino de 39 anos de idade, com linfocitopenia T CD4+, que não estava infectada por vírus imunossupressores nem foi submetida a terapias imunossupressoras. Comentários: Durante o acompanhamento da paciente, ela apresentou níveis muito baixos de ferritina sérica e, após a terapia parenteral de ferro, houve aumento da quantidade de células CD4+, indicando que, neste caso, linfocitopenia era secundária à sideropenia. A paciente estava sendo mantida sob rigoroso controle de ferro sérico e avaliação imunológica periódica, e não mostrou quaisquer eventos adversos clínicos e/ou laboratoriais até o momento. Com base em mudanças na reatividade imunológica dos pacientes observadas por outros pesquisadores após a suplementação com ferro, é evidente que a deficiência de ferro seria um fator importante na gênese das alterações imunológicas que ocorrem em pacientes com anemia ferropriva. É importante compreender os efeitos da deficiência de ferro no sistema imune, devido à sua elevada prevalência mundial. Essas informações também auxiliariam a esclarecer vários casos de linfocitopenia T CD4+ idiopática.
\end{abstract}

Palavras-chave: T-Linfocitopenia Idiopática CD4-Positiva. Deficiência de Ferro. Relatos de Casos.

1. PhD. Biomédica, Universidade Federal do Triângulo Mineiro (UFTM), Uberaba/MG - Brasil

2. MD. Médica, Universidade Federal de Uberlândia, Uberlândia/ MG - Brasil.

3. Biomédica, Hemocentro Regional de Uberaba / Fundação Hemominas, Uberaba/MG - Brasil.

4. PhD. Docente da Disciplina de Hematologia e Hemoterapia, UFTM.

This work was developed at the Universidade Federal do Triângulo Mineiro - Uberaba / MG Brazil.
Corresponding:

Helio Moraes de Souza

Disciplina de Hematologia e Hemoterapia, Hemocentro Regional de Uberaba Universidade Federal do Triângulo Mineiro Av. Getúlio Guaritá, 250. Bairro Abadia Uberaba/MG, Brazil

Recebido em 19/02/2016

Aprovado em 26/10/2017 


\section{Introduction}

Idiopathic CD4 lymphocytopenia (ICL) is a rare syndrome characterized by the total $\mathrm{CD}^{+}$cell count lower than 300 cells/ $\mu$ l, or lower than $20 \%$ of T lymphocytes, in adults. There is often no laboratory evidence of infection by the human immunodeficiency virus (HIV-1 or HIV-2) or by the human Tlymphotropic virus (HTLV-1 or HTLV-2) in patients with $\mathrm{ICL}$, and there is absence of depression-related $\mathrm{CD} 4^{+} \mathrm{T}$ lymphocyte therapy.

Even though establishing the presence of lymphocytopenia in an HIV-uninfected patient with an opportunistic infection is relatively straightforward, determining whether the patient has ICL is not. The differential diagnosis of ICL is broad ${ }^{1}$ so it is made by exclusion and requires an extensive immunologic, hematologic, rheumatologic and infectious disease workup, as well as follow-up testing to confirm the persistence of lymphocytopenia. As stated in the syndrome definition, other forms of immunodeficiency have to be excluded and the provisional ICL diagnosis must be confirmed by a laboratory test at least twice within 1 to 3 months. A comprehensive immunologic workup must be performed in order to exclude HIV infection, lymphoma, autoimmune diseases, other forms of immunodeficiency (such as common variable immunodeficiency), and sarcoidosis. $^{2}$

In cases without any immunosuppressive conditions such as the aforementioned, it is difficult to identify the causative agent of lymphocytopenia, making the cure/permanent improvement of the patient virtually impossible.

\section{Case Report}

BVS, a 39-year-old female patient, was admitted for the first time at the Hematology Outpatient Care at the Clinic Hospital of Federal University of Triangulo Mineiro (HC/UFTM) in 2002. The patient had leukopenia for two years, but had no clinical signs and/or complications.

In the first evaluation, the patient weighed $47 \mathrm{~kg}$, measured $1.71 \mathrm{~m}$ in height, and had a BMI of $16.1 \mathrm{~kg} / \mathrm{m}^{2}$. Hematological levels were as follows: hemoglobin $(\mathrm{Hb})$ was $11.6 \mathrm{~g} / \mathrm{dL}$, leukocytes were $3.0 \times 10^{9} / \mathrm{L}\left(1.8 \times 10^{9}\right.$ neutrophils/L and $1.1 \times 10^{9}$ lymphocytes/L), and platelets were $109 \times 10^{9} / \mathrm{L}$.
She did not present lymph node enlargement, hepatosplenomegaly on physical examination.

The patient was monitored monthly with hematology controls, at first, and then semianually until February 2008, with $\mathrm{Hb}$ ranging from 11 to $12.7 \mathrm{~g} /$ $\mathrm{dL}$, leukocytes ranging from 3.2 to $4.7 \times 10^{9} / \mathrm{L}$ (neutrophils between 1.9 and $3.4 \times 10^{9} / \mathrm{L}$, and lymphocytes between 0.7 and $1.6 \times 10^{9} / \mathrm{L}$ ). The patient interrupted the follow-up, returning to the hospital only in July 2011, referring pharyngitis, sinusitis and recurrent urinary infections, with increased levels of IgM. She had been taking prophylactic nitrofurantoin and sulfa drugs for the last four months, and these complications were controlled. On that occasion, the patient's hemoglobin was $11.9 \mathrm{~g} / \mathrm{dL}$ and leukocytes were $3.5 \times 10^{9} / \mathrm{L}$ (lymphocytes were 0.9 $\times 10^{9} / \mathrm{L}$ ), as follows: CD4 ${ }^{+} \mathrm{T}$ cell count was 90 cells/ $\mu \mathrm{L}, \mathrm{CD} 8^{+} \mathrm{T}$ cell count was 119 cells/ $\mu \mathrm{L}$ (CD4/CD8: $0.75), \mathrm{CD} 19^{+}$cell count was 187 cells $/ \mu \mathrm{L}$, and CD56 ${ }^{+}$ $\mathrm{T}$ cell count was 49 cells $/ \mu \mathrm{L}$. The other tests are listed in Table 1.

Twenty days later, the patient was asymptomatic, with $13.8 \mathrm{~g} / \mathrm{dL}$ hemoglobin, $5.9 \times 10^{9} / \mathrm{L}$ leukocytes $\left(1 \times 10^{9} /\right.$ L lymphocytes $)$ and $232 \times 10^{9} /$ L platelets. The clinical examination was normal, despite that fact that she had low body weight ( $46 \mathrm{~kg}, \mathrm{BMI}$ : $15.7 \mathrm{~kg} / \mathrm{m}^{2}$ ) and anorexia, with low food intake for several years. After nutritional evaluation, the patient was subjected to a high calorie and high protein diet, and gained six kilos (52 kg, BMI: $17.8 \mathrm{~kg} /$ $\mathrm{m} 2$ ). At this moment, hemoglobin level was $12.5 \mathrm{~g} /$ dl, but ferritin level was $7.3 \mu \mathrm{g} / \mathrm{L}$, and $\mathrm{CD}^{+}$and $\mathrm{CD}^{+}$lymphocytes remained virtually unchanged (Table 1).

During the evaluation period, aspiration and biopsy of the bone marrow were performed and significant changes in myelopoiesis were not observed at any time.

Iron therapy was started, and four months later the patient's hemoglobin was $13.6 \mathrm{~g} / \mathrm{dL}$, ferritin was $83.5 \mu \mathrm{g} / \mathrm{L}$, and the levels of $\mathrm{CD}^{+}{ }^{+}$and $\mathrm{CD} 8^{+}$ $\mathrm{T}$ cells had been repaired (Table 1 ).

\section{Discussion}

Despite twenty years of research, ICL remains a syndrome of uncertain pathogenesis, prognosis and treatment. Although a subgroup of patients remain asymptomatic, other patients may continue 
Table 1. Values of CD3, CD4, CD8, CD19, CD56 cell quantification, CD4/CD8 ratio, IgG, IgM and IgA immunoglobulins and ferritin levels of patient, during her treatment period at the Clinic of Hematology of HC/UFTM.

\begin{tabular}{|c|c|c|c|c|c|c|c|}
\hline & $02-22-05$ & $04-06-11$ & $07-08-11$ & $12-12-11$ & 04-17-12 & $06-22-12$ & Reference values \\
\hline \multicolumn{8}{|c|}{ Phenotyping } \\
\hline CD3 & - & $\begin{array}{c}336 \text { cells } / \mu \mathrm{L} \\
(69.4 \%)\end{array}$ & $\begin{array}{l}210 \text { cells } / \mu \mathrm{L} \\
(64.9 \%)\end{array}$ & 302 cells $/ \mu \mathrm{L}$ & 1,009 cells $/ \mu \mathrm{L}$ & 887 cells/ $\mu \mathrm{L}$ & $\begin{array}{c}1,000-3,900 \text { cells } / \mu \mathrm{L} \\
(55 \%-82 \%)\end{array}$ \\
\hline CD4 & - & $\begin{array}{c}161 \text { cells } / \mu \mathrm{L} \\
(30.4 \%)\end{array}$ & $\begin{array}{l}90 \text { cells } / \mu \mathrm{L} \\
(27.7 \%)\end{array}$ & 118 cells $/ \mu \mathrm{L}$ & 569 cells/ $\mu \mathrm{L}$ & 459 cells/ $\mu \mathrm{L}$ & $\begin{array}{c}359-1,725 \text { cells } / \mu \mathrm{L} \\
(27 \%-57 \%)\end{array}$ \\
\hline CD8 & - & $\begin{array}{l}- \\
(36.7 \%)\end{array}$ & 119 cells $/ \mu \mathrm{L}$ & 154 cells $/ \mu \mathrm{L}$ & 516 cells $/ \mu \mathrm{L}$ & $\begin{array}{l}376 \text { cells } / \mu \mathrm{L} \\
(14 \%-34 \%)\end{array}$ & $300-1,000$ cells $/ \mu \mathrm{L}$ \\
\hline CD19 & - & $\begin{array}{l}- \\
(12.7 \%)\end{array}$ & 187 cells/ $\mu \mathrm{L}$ & - & - & $\begin{array}{c}- \\
(6 \%-17 \%)\end{array}$ & $90-680$ cells $/ \mu \mathrm{L}$ \\
\hline CD56 & - & - & $5.2 \%$ & - & - & $\begin{array}{c}- \\
(6 \%-29 \%)\end{array}$ & $75-500$ cells $/ \mu \mathrm{L}$ \\
\hline CD4/CD8 & - & - & 0.75 & 0.77 & 3.20 & 1.22 & $0.98-3.24$ \\
\hline \multicolumn{8}{|c|}{ Immunoglobulins } \\
\hline IgG & - & $10.4 \mathrm{~g} / \mathrm{L}$ & - & $10.7 \mathrm{~g} / \mathrm{L}$ & - & $9.7 \mathrm{~g} / \mathrm{L}$ & $5.3-16.5 \mathrm{~g} / \mathrm{L}$ \\
\hline IgM & - & $7.7 \mathrm{~g} / \mathrm{L}$ & - & $3.0 \mathrm{~g} / \mathrm{L}$ & - & $2.5 \mathrm{~g} / \mathrm{L}$ & $0.5-2.0 \mathrm{~g} / \mathrm{L}$ \\
\hline $\operatorname{IgA}$ & - & $1.2 \mathrm{~g} / \mathrm{L}$ & - & $1.4 \mathrm{~g} / \mathrm{L}$ & - & $0.9 \mathrm{~g} / \mathrm{L}$ & $0.8-4.0 \mathrm{~g} / \mathrm{L}$ \\
\hline Ferritin & $17.8 \mu \mathrm{g} / \mathrm{L}$ & - & - & $7.3 \mu \mathrm{g} / \mathrm{L}$ & $83.5 \mu \mathrm{g} / \mathrm{L}$ & $30.5 \mu \mathrm{g} / \mathrm{L}$ & 15.0 a $300 \mu \mathrm{g} / \mathrm{L}$ \\
\hline
\end{tabular}

Reference values: JAMA Instructions for Authors, 1997.

to develop fatal opportunistic infections ${ }^{3}$ or autoimmune diseases. ${ }^{4}$ Increased levels of IgM (> 3X the normal range) were observed in the patient on $6^{\text {th }}$ April 2011. At this time, the patient had multiple infectious complications, which probably led to increased levels of this immunoglobulin. These values decreased to almost reach the limits of normal levels $(2.5 \mathrm{~g} / \mathrm{L})$ on $17^{\text {th }}$ April 2012, when CD4 and CD8 $T$ cell levels were within normal limits and there were no infectious complications.

The decrease in IgM levels from 7.7 to $3.0 \mathrm{~g} / \mathrm{L}$ in three months and to $2.5 \mathrm{~g} / \mathrm{L}$ in twelve, the normal results found in bone marrow aspirations and bone marrow biopsy and the absence of monoclonal peak excluded the possibility of monoclonal gammopathy and Waldenström Macroglobulinemia.

In 2005, the patient's ferritin levels were near the lower normal limits. Sideropenia was not investigated more thoroughly because, at that time, the patient was asymptomatic, with only mild leukopenia, neutropenia and lymphocyte levels near the lower normal limits. In 2011, when the patient had infectious complications, assessment showed that she had very low levels of serum ferritin. As the patient denied gastrointestinal blood loss and hypermenorrhea, and the fecal occult blood test performed before iron therapy was negative, we suspected that sideropenia could be due to chronic malnutrition.

The low and inadequate chronic intake of nutrients was responsible for malnutrition and anemia of the patient, since, in both the nutritional questioning carried out by the nutritionist and in the clinical evaluations, the low consumption of carbohydrates, proteins and iron was documented. However, it was also demonstrated by the persistence of low ferritin levels after improvement of the patient's nutritional status that the iron intake was not sufficient to correct their deficiency. As reported in clinical consultations, the patient reported great difficulties in eating foods rich in proteins such as meats and eggs and intolerance to oral iron therapy, which justifies the non-correction of ferritin levels. The rapid correction of $\mathrm{CD} 4^{+}$and $\mathrm{CD} 8^{+} \mathrm{T}$ cell levels 
following the introduction of parenteral iron therapy suggests that immunological deficiency was related to iron deficiency, which in turn was caused by protein-calorie mineral malnutrition.

Tichelli et al. (1992) found that anemia is accompanied by slight leukopenia in one third of the patients, and platelet counts may be normal, increased or decreased. ${ }^{5}$ After parenteral iron therapy, $\mathrm{CD}^{+}, \mathrm{CD}^{+}{ }^{+}$and $\mathrm{CD}^{+} \mathrm{T}$ cells were found to be improved, corroborating the hypothesis that, in this case, lymphocytopenia was secondary to iron deficiency. Chronic idiopathic neutropenia of adults was also found in individuals with iron deficiency, and the recovery or improvement of neutrophil count was observed upon iron supplementation. ${ }^{6}$

It is known that iron is essential for the normal development of the immune system - it is an important peroxide compound of nitric oxide generating enzymes, and it generates enzymes that are critical to the proper enzymatic functioning of immune cells. ${ }^{7}$

Santos and Falcão (1990) found immunological abnormalities in patients with iron deficiency anemia (IDA), which increased susceptibility to infections. ${ }^{8}$ They evaluated subpopulations of lymphocytes in the peripheral blood of 21 patients with IDA. The results showed that the average number of total T cells $\left(\mathrm{CD}^{+}\right.$and $\left.\mathrm{CD}^{+}\right)$, as well as $\mathrm{B}$ lymphocyte subsets, were reduced in these patients compared with control subjects.

In another study, significantly lower levels of $\mathrm{T}$ lymphocytes, as well as $\mathrm{CD} 4^{+} \mathrm{T}$ cells, were found in iron-deficient children in comparison with healthy children. ${ }^{9}$ The CD4/CD8 ratio was found to be significantly lower in the first group. In accordance with these findings, there was a significant increase in $\mathrm{CD}^{+} \mathrm{T}$ cells after oral iron supplementation. The same was observed by Das et al. (2014) in a study with 40 iron-deficient children and by Sejas et al. (2008), who stated that IDA in children can significantly affect circulating immature lymphocyte subpopulations. ${ }^{10,11}$ They also observed that iron supplementation significantly improved CD4+ T cell counts and $\mathrm{CD} 4: \mathrm{CD} 8$ ratios.
A similar reduction in lymphocyte counts was also observed in pre-menopausal women with IDA. Lymphocyte subsets were studied in 50 adult premenopausal women with iron deficiency anemia (microcytic hypochromic anemia) and the results were compared with healthy women. There were significant differences in T cell counts, both in helper $T$ cells and cytotoxic $T$ cells, between the case and the control groups. ${ }^{12}$

Based on changes in immune reactivity of patients observed after iron replacement, it is evident that iron deficiency is an important factor in the genesis of immunological changes that occur in patients with IDA. There are several possible mechanisms that may explain the effects of iron deficiency on the immune system. Neutrophils have a reduced activity of myeloperoxidase, an iron-containing enzyme which produces reactive oxygen intermediates (ROI) that are responsible for intracellular killing of pathogens. ${ }^{13}$ In vitro studies have shown that there is a direct correlation between iron deficiency and impaired T-lymphocyte proliferation. There is a decrease in T-lymphocyte blastogenesis and mitogenesis in response to a number of different mitogens. ${ }^{7}$ Furthermore, iron deficiency induces atrophy of the thymus in laboratory animals and in humans, resulting in reduction of $\mathrm{T}$ cell proliferation and/or differentiation. ${ }^{14}$

Iron deficiency is the most common known form of nutritional deficiency in the world. It is a major health problem in developed and developing countries. Therefore, it is important to understand the effects of this deficiency on the immune system given its high prevalence. According to evidence in the literature showing a close relationship between iron and immune system functioning, we concluded that this is a case of CD4 lymphopenia secondary to sideropenia. The patient is being kept under strict control of serum iron and periodic immunological evaluation, and she has showed no clinical and/or laboratory adverse events so far. Immunologists and hematologists should work together to integrate this type of information in order to resolve questions such as those presented herein. 


\section{References}

1. Walker UA, Warnatz K. Idiopathic CD4 lymphocytopenia. Curr Opin Rheumatol. 2006; 18: 389-95.

2. Zonios D, Sheikh V, Sereti I. Idiopathic CD4 lymphocytopenia: a case of missing, wandering or ineffective $T$ cells. Arthritis Res Ther. 2012;14:222.

3. Said S, Alkhateeb H, Cooper CJ, Rodriguez E, Trien R, Hernandez GT, Salameh HS. Idiopathic CD4+ Iymphocytopenia in Hispanic male: case report and literature review. Int Med Case Rep J. 2014; 7: 117-20.

4. Morimoto C, Reinherz EL, Distaso JA, Steinberg AD, Schlossman SF. Relationship between systemic lupus erythematosus $\mathrm{T}$ cell subsets, anti-T cell antibodies, and $\mathrm{T}$ cell functions. J Clin Invest 1984; 73: 689-700.

5. Tichelli A, Gratwohl A, Speck B. Iron-deficiency anemia: diagnosis and therapy. Schweiz Med Wochenschr. 1992; 122: 461-5.

6. Lima CS, Paula EV, Takahashi T, Saad ST, Lorand-Metze I, Costa FF. Causes of incidental neutropenia in adulthood. Ann Hematol. 2006; 85: 705-9.

7. Beard JL. Iron biology in immune function, muscle metabolism and neuronal functioning. J Nutr. 2001; 131: 568S$580 \mathrm{~S}$.

8. Santos PC, Falcão RP. Decreased lymphocyte subsets and K-cell activity in iron deficiency anemia. Acta Haematol. 1990; 84: 118-21.
9. Mullick S, Rusia U, Sikka M, Faridi MA. Impact of iron deficiency anaemia on T lymphocytes \& their subsets in children. Indian J Med Res 2006; 124: 647-54.

10. Das I, Saha K, Mukhopadhyay D, Roy S, Raychaudhuri G, Chatterjee M, Mitra PK. Impact of iron deficiency anemia on cell-mediated and humoral immunity in children: $A$ case control study. J Nat Sci Biol Med. 2014; 5: 158-63.

11. Sejas E, Kolsteren PK, Hoeree T, Roberfroid N. Iron supplementation in previously anemic Bolivian children normalized hematologic parameters, but not immunologic parameters. J Trop Pediatr. 2008; 54: 164-8.

12. Reza Keramati $M$, Sadeghian $\mathbf{M H}$, Ayatollahi $\mathrm{H}$, Mahmoudi M, Khajedaluea M, Tavasolian H, Borzouei A. Peripheral Blood Lymphocyte Subset Counts in Pre-menopausal Women with Iron-Deficiency Anaemia. Malays J Med Sci. 2011; 18: 38-44.

13. Spear AT, Sherman AR. Iron deficiency alters DMBA-induced tumor burden and natural killer cell cytotoxicityrats. J Nutr. 1992; 122: 46-55.

14. Moraes-de-Souza H, Kerbauy J, Yamamoto M, da-Silva MP, dos-Santos MR. Depressed cell-mediated immunity in iron-deûciency anemia due to chronic loss of blood. Braz J Med Biol Res. 1984; 17: 143-50. 